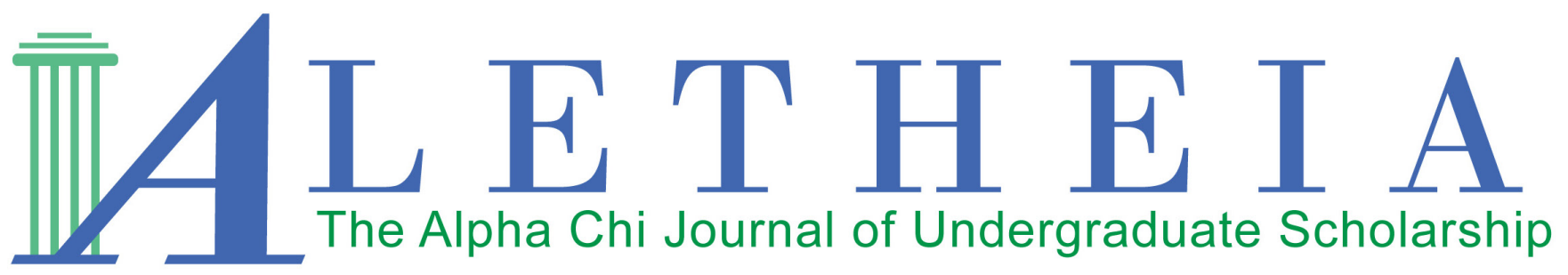

Volume 2 | Issue 2 | 2017

\title{
Feminisms in the Middle East: Making strides from the margins
}

\author{
Alyx Olney
}

\author{
Hastings College \\ Nebraska Alpha Chapter
}

Vol. 2(2), 2017

Article Title: Feminisms in the Middle East: Making strides from the margins

DOI: $10.21081 / \mathrm{AX} 0108$

ISSN: 2381-800X

Key Words: feminism(s), Islam, Middle East, social movement

This work is licensed under a Creative Commons Attribution 4.0 International License.

Author contact information is available from the Editor at editor@alphachihonor.org.

\section{Aletheia-The Alpha Chi Journal of Undergraduate Scholarship}

- This publication is an online, peer-reviewed, interdisciplinary undergraduate journal, whose mission is to promote high quality research and scholarship among undergraduates by showcasing exemplary work.

- Submissions can be in any basic or applied field of study, including the physical and life sciences, the social sciences, the humanities, education, engineering, and the arts.

- Publication in Aletheia will recognize students who excel academically and foster mentor/mentee relationships between faculty and students.

- In keeping with the strong tradition of student involvement in all levels of Alpha Chi, the journal will also provide a forum for students to become actively involved in the writing, peer review, and publication process.

- More information and instructions for authors is available under the publications tab at www.AlphaChiHonor.org. Questions to the editor may be directed to editor@alphachihonor.org.

\footnotetext{
Alpha Chi is a national college honor society that admits students from all academic disciplines, with membership limited to the top 10 percent of an institution's juniors, seniors, and graduate students. Invitation to membership comes only through an institutional chapter. A college seeking a chapter must grant baccalaureate degrees and be regionally accredited. Some 300 chapters, located in almost every state, induct approximately 12,000 members annually. Alpha Chi members have been "making scholarship effective for good" since 1922.
} 


\title{
Feminisms in the Middle East: Making strides from the margins
}

\author{
Alyx Olney \\ Hastings College \\ Nebraska Alpha Chapter
}

\begin{abstract}
In this critical dissection of a social movement, I analyze aspects of feminisms in the Middle East. I look critically at the goals, grievances, and actors of the movements, discuss the development of the movements, and analyze the ways in which marginalized feminisms in the Middle East operate. I determine that though there are at least two distinct strands of feminist thought and social action in the Middle East, secular feminism and Islamic feminism, their patterns of development do not mimic Western feminisms. It is critical to be culturally relative when examining social movements and their strategies and successes.
\end{abstract}

Key words: feminism(s), Islam, Middle East, social movement

The film Suffragette (2015) is a historically-based film starring Meryl Streep that follows the struggle of women in the UK to get the right to vote. The movie sends a powerful message and provides a powerful image for what many consider "the feminist movement," particularly of first wave feminism. When many Americans think of feminisms and history, and of feminist movements, the picture they get probably looks a lot like this movie. It involves strong, middle and upper class white women in Western nations fighting for their rights. This particular picture comes to mind when people think of feminist movements because the women who led them were privileged, and white class privilege became a feature of the movements themselves. In addition, the history of Western colonization has framed feminism itself as a Western project. Early moments of the feminist movements in Europe and the US, which are the most recognizable feminist movements, look much alike; there is a distinct lack of diversity in terms of race, ethnicity, religion, class, and nationality.
This is not to say that modern Western feminisms do not include prominent movements organized and informed by women of color, as well as scholarship that moves well beyond white, middle class feminisms. In particular, scholarship about intersectional feminisms and research using an intersectional lens has dramatically increased since Crenshaw's (1991) first use of the term "intersectionality." Intersectional feminist scholarship is largely interdisciplinary and has further developed the concept, moving feminist movements into new, more promising practices (Anzaldúa, 1987; Cho \& Ferree, 2010; Lugones, 2007; Quesada \& Vidal-Ortiz, 2015; Richie, 2012).

However, white feminisms in the Western world remain dominant. Failing to acknowledge such dominance is nothing more than a disservice to the work of feminist scholars and social action organizers of color. Here it is important to note that my critique lies not with feminist scholarship or social action separately, but with both of them together. The work done in academia by 
feminist scholars is informed and shaped by the onthe-ground work that various social movement actors do every day. Further, the action organized by social movements is influenced by academia. Both sides are informed by each other in a complicated and cyclical process. This is one more way of highlighting why feminist movements led by women of color, poor women, and women outside the Western world are legitimate and important movements. These movements place feminisms within non-privileged geographies, including contexts related to different regions, cultures, religions, races, and ethnicities. Specifically, in this paper I look at non-Western feminisms, focusing on the Middle East or MENA region and predominantly Islamic countries. Non-Western feminisms include several strands, each of which has its own specific emphasis and cultural nuance. I will examine two strands. Following the work of feminist scholars and activists in these movements, I refer to these movements as Islamic feminism and secular feminism (e.g., Abu-Lughod, 1998; Ahmadi, 2006; Ahmed, 1982; Badran, 2005; Cervantes-Altamirano, 2013; Seedat, 2013).

Islamic feminism is grounded in Islamic teachings. The actors in this movement seek to enact change within the Islamic framework. Actors in this movement often seek to find and support interpretations of the Quran that promote more gender equality. Secular feminism in the Middle East, in contrast, seeks change outside of an Islamic framework. It is not grounded in religion, which means that it has the freedom to work counter to the religious framework present in these countries. Both of these strands are present in the Middle East, and, since these strands have some goals and grievances in common, they sometimes work toward the same goal. Other times, the context of each strand puts them at cross purposes and conflict arises between the movements. In essence, Islamic feminism is focused on reform whereas secular feminism is focused on rejecting the gender inequality dictated by Islamic theocratic social systems. In this discussion, terminology is important. First-world feminisms and Western feminisms both typically refer to more mainstream feminisms that centrally emphasize the demands of middle-to upper-class white women present in the Western world, such as the US and the UK. On the other hand, I am using the term "non-Western feminisms" as an umbrella term to include both strands of the feminisms that I am examining in this paper. Later, I will use the term "marginalized feminisms" in con- junction with the term "non-Western feminisms" to describe the collective feminisms in the Middle East.

The Middle East is dominated by male power-a patriarchy, as is the Western world - and is heavily influenced by traditional interpretations of Islamic values. The relation between church and state, though varying from country to country, remains fairly unequivocal. Politicians often wield as much practical power as prominent religious leaders . Generally speaking, these Middle Eastern countries are not capitalist democratic societies, and their track record with leading capitalist democratic countries is sometimes turbulent. Thus, in the Middle East "there is considerable unease about 'feminism,' a lack of awareness of Middle Eastern . . . feminist history/ies, and an inability to move beyond the notion that feminism is Western and a colonial imposition" (Badran, 2005, p. 15). This assumption is, of course, fair, as Western feminisms cast a long wide shadow. While the basis of feminism is rooted in first-world, capitalist democratic societies, and multiple branches of feminism have stemmed from this ideal type of first-world feminism, the feminisms of the Western and non-Western worlds are not one in the same. When considering that both Western feminisms and non-Western feminisms fight to increase the rights of women, the movements share some goals and grievances. In many ways, these feminisms are fighting for the same things through the lenses of their respective cultures. However, what characterizes these social movements is as much related to how they differ as to how they are similar.

Western feminisms and non-Western feminisms can be classified in opposition to each other just as easily as they could be considered companion movements. As Ahmadi (2006) explains, "[w]omen who try to defend their rights in Muslim contexts often are accused of importing a foreign ideology . . . . Thus, many Islamic feminists first try to demonstrate that they are truly and genuinely rooted in their culture ... to distinguish themselves from 'Western feminists,' as, for instance, 'Third World feminists"' (p. 44). These two movements can easily be in conflict with each other because the cultural and historical contexts in which each is grounded are opposed to one another. Mainstream Western feminist perspectives view gender inequality and women's rights through the lens of the capitalist democratic society, and until the 1980s focused primarily on white middle and upper class women's rights. Non-Western feminisms are often deeply rooted or influenced by a traditional inter- 
pretation of Islam, whether or not the change those movements seek falls within that framework, which does not reflect the capitalist democratic ideology. Understanding non-Western feminist movements and Western feminist movements requires seeing how those movements are rooted in cultural norms and in forms of government.

\section{Movement Development, Visibility, and Grievances}

Though feminist thought in the Middle East has existed for some time, the ability to organize social action has been limited. For a variety of reasons, including lack of resources and the level of personal risk that involvement in social action would cause, social movement action has been stealthy, sporadic, and largely undocumented. This timeline of social action demonstrates those characteristics and provides a brief history of Islamic feminism and secular feminism in the Middle East.

In 1979, the Iranian Revolution caused a resurgence of Islamic fundamentalism in Iran and in other places in the Middle East (Abu-Odeh, 1993; Ahmadi, 2006). This was a precipitating event in the development of these feminist movements. Without this fierce re-Islamization, there would have been little to no backlash in terms of feminist thought. The year 1990 marks the early emergence of a new feminism in the Middle East known as 'Islamic Feminism' (Badran, 2005). In 1992, the journal Zanan was founded and became an influential platform for social justice and gender equality for Muslim women in the Middle East (Badran, 2005; “Timeline," 2015). Shirin Ebadi, a human rights activist from Iran, won the Nobel Peace Prize in 2003 (Ebadi, 2003; "Timeline," 2015). This was a key moment for these movements: Ebadi winning the Nobel Peace Prize carried significant symbolic value and was a success in terms of goals and awareness. In 2006, the One Million Signatures Campaign in Iran was launched with the main goal of abolishing laws that are discriminatory against women or support gender inequality. Additionally, the campaign sought to change the local culture that supported these laws (Women's Learning Partnership; International Campaign for Human Rights in Iran, 2011; Tavaana, 2015). Also in 2006, the Stop Stoning Forever Campaign was launched with the goal of changing the Iranian Penal Code (Amini, 2008; Stop Stoning Forever Campaign, 2006; "Timeline," 2015). In 2009, Iranian women took to the streets to protest the country's leadership and to defend their rights as women and as citi- zens (Basu, 2009; Raghavan, 2009; “Timeline,” 2015). In 2011, women played an active role in the Arab Spring protests ("Timeline," 2015) and the online "Women2Drive" initiative started and gained global attention in response to the arrest of Manal al-Sharif. The campaign urged Saudi Arabian women to post pictures of themselves or the people they were with driving in protest of the "unofficial" Islamic driving ban. This was accompanied by the hashtag \#Women2Drive (Jamjoon, 2011; Malik, 2011; “Timeline," 2015). More recently, in 2014 and 2015, Iranian women posted hijab-less pictures online in protest of the strict dress laws in Iran (Earth Porm, 2015).

Though it has taken decades for these non-Western feminist movements to become more than highly unorganized sporadic social action, their goals are quite clear. Both Islamic feminism and secular feminism have several goals focused on securing rights for women. Among these are the right to drive, the right to dress less restrictively, and the right to be in the public sphere unaccompanied. Secular and Islamic feminist movements also have the shared grievance that Western feminisms do not acknowledge their voices or reflect their interests. Many Islamic feminists feel that mainstream Western feminist perspectives disregard their culture and their religion in the quest to help them discover sexual liberation (Abu-Odeh, 1993). Such an approach from Western feminisms is culturally incompatible and ethnocentric. In the academic literature, scholars such as Abu-Lughod (1998) assert that "the field continues to be dominated (even after the gestures toward difference, multiculturalism, race, and so forth) by people who work on Euro-American societies and white women and men" (p. $25)$. That statement was made over 15 years ago, yet it largely holds true today. This problem extends much further than just the feminist academy, which is dominated by white women; the world of feminist thought continues to be dominated by a culture of white supremacy. Previously I used the term "marginalized feminisms" to describe these feminisms. I did this because the term illuminates the issues and the perspective of traditionally marginalized people. Many of the women in these countries, and especially the actors involved in these movements, effectively argue that their problems are not addressed by white Western feminisms. In response, Middle Eastern feminist movements give a platform and spotlight to the perspectives that serve women in those cultures, eschewing the oppressive and poorly matched perspectives of Western feminisms. 
Both Islamic and secular feminist movements reject Western feminisms. They also share some grievances against their own culture, although there are differences as well. The shared grievances among Middle Eastern feminist movements include critiques of the absence of the human rights that are widely available to men. Another common position is that women in these countries are oppressed both by the laws and the common interpretation of Islam, though their approaches to handling that specific grievance are wildly different. Many Middle Eastern countries have laws connected to crimes of honor. Honor crimes can be explained as crimes committed to defend or preserve one's honor or the honor of one's family (Wilkinson, 2012). For example, AbuOdeh (1993) describes a situation in which a brother killed his sister because she was seen fraternizing in public with a man to whom she was not related. Her actions shamed the family and her brother's reputation. Abu-Odeh explains, "After trial, the brother is imprisoned for one year only. His extenuating circumstance is committing a 'crime of honour,' sanctioned in most Arab penal codes" (p. 1527). Women in the Middle East face these dangers, which may prompt non-Western feminists to become engaged in social action and other social movement campaigns to change the laws and culture that support honor killing and other institutionalized forms of oppression. However, secular and Islamic feminists may employ very different strategies to meet similar ends due to their sometimes differing goals. While honor crimes, among many other very real and present dangers to women in the Middle East, are of concern to feminists in both camps, secular feminists in this situation may find fault with the cultural influence that Islam has on the penal code and justice system, whereas Islamic feminists may in turn place blame on the very traditionalist interpretation of Islam which condones and promotes honor crimes. To that end, there are multiple instances in which these non-Western feminists may equally take issue with the same instances of oppression but look in very distinct directions to find their solution.

\section{Resources, Mobilization, and the Protest Cycle}

The main actors in Middle Eastern feminist movements, no matter what strand, tend to be young, educated women from upper-middle class families. Abu-Odeh (1993) explains that "most Arab feminists are upper or middle class women, with material resources that enable them to avoid, to a great extent, uncomfortable experiences" (p. 1533). It makes sense that the most prominent social actors are the most privileged section of the under-privileged population since these women have more access to resources such as time and money. In addition, their privilege may protect them from harmful consequences of being engaged in feminist social action. Not all actors fit into this category, however, and in both Islamic and secular feminist movements people from a variety of backgrounds are involved. Nevertheless, the relative privilege that many of these women experience serves both as a resource for the movement itself and a bone of contention within each of the movements. Often movement leaders are especially knowledgeable about law, government, and social systems. They use social media to educate potential movement actors and allies about their goals, shared grievances, and successes. However, since movement actors are in large part class-privileged and educated Muslim women, lack of representation even within the movements is a credible claim. Higher-class women do not and cannot understand the struggles that lower-class women experience.

Of the many stakeholders involved in secular and Islamic feminist movements, the most obvious are Middle Eastern women living in Islamic countries. Young girls are also stakeholders because, while they may not have as many rights as underage minors, this movement fights for the rights they may or may not have in the future. Additionally, child marriage is an issue for several non-Western feminist movements. Political and religious leaders are also stakeholders because many of the shared grievances for movement actors are in opposition to the current political or religious system. Generally in these countries men are also stakeholders because they currently have many of the rights the women lack, and because they have the power to help women gain access to those rights. One more very important stakeholder group includes those men and women who are invested in more conservative interpretations of Islam. Their stake in the movement locates them in opposition particularly to the strand of Islamic feminism, but at times places them in opposition to both strands. Stakeholders, as it is easy to see, lie on all sides of these movements.

Many of the problems and shared grievances of Islamic and secular feminist movements are rooted in the strain between traditional and modern ideas about what it means to be a woman. Norms, which are "written and 
unwritten expectations for behavior, thought, and appearance deemed appropriate to a particular social situation" (Ferrante, 2016, p. 55), are difficult to change and often efforts to do so spark controversy and strong emotions. As difficult as it may be, changing the norms surrounding gender and the role of women is exactly what many Islamic feminists are trying to do. For these women, rather than "pointing to Islam as the inherent root of female discrimination ... [they point to] state actors or elites as the culprits ... Islamic feminists embrace their faith, culture and tradition while fiercely advocating for legislative reforms and interpretations that reflect a more modern understanding of the woman's role in society" (Boland, 2014, para. 4). This both promotes an unpopular interpretation of Islam and impugns men in leadership, challenging traditional views and hierarchies of power. The controversy inherent in this view is apparent, and is made more visible by the force of the opposition Islamic feminism faces. The Islamic feminist movement's modern view of the role and rights of women is also reflected in its resistance of the restrictive dress expected or required of Muslim women. Emotions have run high in recent years between both the movement and the opposition. In response to the "3.6 million women ... [warned, fined, or arrested] for charges related to inappropriate dress" (Earth Porm, 2015 para. 1) in Iran, many Muslim women have been posting pictures online courageously displaying their hair flowing freely, despite laws requiring women to wear the hijab. Even something as basic as dress has deep roots in cultural tradition, and making a change to it can result in a heated, and sometimes even dangerous, response or backlash.

Non-Western feminists had not organized much social action prior to the past two decades. One reason for the increase in feminist social action from Islamic feminists and secular feminists is the ability to use the internet. The internet helps mobilize resources, particularly social networks, while sometimes also providing the cover of anonymity. Anonymity allows movement actors to avoid negative consequences for engaging in social movement politics, which is particularly important for secular feminists who might be viewed as enemies of the state. Those in opposition to the movement include men in positions of legal and practical power. These men may even live in the same households as movement actors. Anonymity allows for increased participation while reducing personal risk. In addition, social media gives social movements and their issues greater visibility to a greater number of people. That can and does help grow the movement and its social and political reach. Social media and the internet facilitate communication between women that is quick, generally safe, inexpensive, and spans across multiple countries all over the world. Using the internet is an easy and convenient way to raise awareness about the movement and its plans and goals, as well as to generate support and raise money. This holds true for both strands of non-Western feminism, since both movements, and especially the women in both movements, may face the same serious consequences for their participation in the movements' action.

Further resources for these movements lie in the multiple social movement organizations that are associated with non-Western feminisms. Some of these organizations deal specifically with social movement goals. The Stop Stoning Forever Campaign is a campaign to officially end the use of stoning as punishment for breaking the law (Amini, 2008). The International Campaign for Human Rights in Iran is focused on increasing awareness and supporting the social action of people in Iran fighting a lack of protection and violations of their basic human rights (International Campaign for Human Rights in Iran, 2011). Iran's One Million Signature Campaign is aimed at ending discriminatory laws against women in Iran (Women's Learning Partnership). Other individual social movement organizations may not deal with a specific social movement goal, but rather with women's rights in the Middle East in a more general sense. Examples of these organizations include the Arab Women's Organization (focusing on including Arab women's issues in the international development agenda) and the Communication Network of Women NGOs of the Islamic Republic of Iran (which exchanges experiences and information among NGOs promoting women's rights) (WISE Muslim Women, n.d.). While these organizations themselves may be resources for both the Islamic and secular feminist movements, they do not situate themselves specifically in an Islamic or secular context. This reiterates the idea that these strands deal with many of the same topics that face stakeholders in their countries. The likely result is that actors from both strands rely on the resources those organizations provide, and the organizations may lend themselves to coalitional-type social action.

Non-Western feminisms do not have a predictable protest cycle, possibly because non-Western feminisms 
have not become consolidated or organized social movements and their work must sometimes be approached with great care. The absence of a visible and predictable protest cycle is also due to the lack of support for social movement action in the non-democratic societies where these movements are geographically rooted. As Badran (2005) explains, "Islamic feminism has yet to become a widely-based social movement, the way [first-world] feminisms became organized movements" (p.14). Without an organized structure, and a safe sociopolitical environment in which to operate, it is difficult to develop and maintain a consistent protest cycle with regular social action.

Much of the social action involved in these movements is political, including multiple petitions and both digital and on-the-ground protests calling for changes in legislation and cultural norms to provide and protect women's rights and civic engagement. One example of social action is the Women2Drive Campaign, an online campaign involving Saudi Arabian women posting pictures of themselves driving on social media to protest the restrictions on women driving. In general, social action for these movements has two goals: structural change and cultural change. The protests, petitions, and other campaigns are working to make structural changes, such as changing the laws that deny women human rights. However, even if they succeed in changing the unjust laws, the culture surrounding such laws may still exist. Without a change in both structure and culture, conditions surrounding gender equality in the Middle East cannot be expected to sustainably change.

Though many of the most prominent social actors come from educated, privileged backgrounds, speaking out may put the personal safety of women of any class at risk, which makes it difficult to start or continue social action. This is certainly an issue that plagues both Islamic feminism and secular feminism. Additionally, the multiple strands of non-Western feminisms can work against each other at the expense of each. Islamic feminism seeks to make change within the Islamic paradigm, but secular feminism does not seek to make change within the paradigm and, in fact, resists that paradigm. Secular feminism pursues goals and uses strategies that discredit or oppose Islamic feminism. Moreover, Islamic feminism may undermine secular feminism's goals and strategies. Islamic feminist and secular feminist movements are taking place in more than one country, which is another challenge for both movements. How one country responds to these movements may be very different than how another country's people and government respond, requiring multiple and sometimes competing strategies within the same social movement. These factors affect the mobilization of resources, which in turn can put an additional strain on social movement goals and strategies.

\section{Media Portrayal and Art}

Islamic and secular feminisms have captured the attention of media, both local and international. While it is useful to have the attention of media that supports the goals of the movement, it might be more effective if the movement received media attention from larger, international sources. In recent years, news platforms giving a voice to the Middle Eastern feminist movements, or even shedding some light on the movement, include, but are not limited to, CNN (Basu, 2009; Jamjoon, 2011; Wilkinson, 2012), The Washington Post (Raghavan, 2009), International Policy Digest (Wagner, 2012), and The Guardian (Malik, 2011). This media attention is more than just a feather in the cap for Islamic and secular feminist movements. Media attention of this caliber, and especially from well-known outlets, lends credibility to a movement itself. Additionally, by increasing awareness of the movements' shared grievances and its goals, media attention can raise support, increase the number of people involved in the movements as members or allies, and aid in mobilizing other resources.

While Islamic and secular feminist movements utilize the internet and social media when mobilizing resources and engaging social networks, both the internet and social media provide an outlet for the movements to exert more control over how movement goals and messages are conveyed. One clear example involves the Women2Drive campaign. This campaign called for multiple Muslim women, specifically in Saudi Arabia, to post pictures of themselves driving, actively disobeying the "unofficial ban" against women driving. In his article for CNN, Jamjoon (2011) explains that "There are no specific traffic laws that make it illegal for women to drive in Saudi Arabia. However, religious edicts are often interpreted as a prohibition of female drivers . . . . Authorities stopped Manal al Sharif, 32, for driving a car May 21 and detained her the next day. She said she was forced to sign a form promising not to drive again and spent a week in jail." Her involvement with the author- 
ities catalyzed social action. In response to what many women consider her unlawful detainment, women began posting pictures of themselves, or those they were with, driving and getting driver's licenses. The Women2Drive campaign also uses art and media to advance the movement and this goal. A multitude of digital images has been created for use specifically for the Women2Drive campaign. In particular, two very common digital images surface when searching \#Women2Drive on Twitter and other social media: the first depicts a woman in a black niqab apparently behind the wheel of a car with the hashtag (\#)WOMEN2DRIVE over the niqab. The second is made to resemble a yellow diamond-shaped caution sign depicting the front-view of a niqab-wearing woman flashing a peace sign out of the window of the car she is driving, with the hashtag (\#)WOMEN2DRIVE on the grill of the car. Both images are minimalistic and the relation to the campaign is clear. Although the Women2Drive campaign is never explicitly categorized, by its own determination or by others, as a product of Islamic feminism or of secular feminism, the clear use of imagery involving the niqab and other articles of modesty indicate the influence of Islamic feminism over secular feminism. Another popular digital image created and utilized by the Women2Drive campaign alters the familiar Western feminist icon Rosie the Riveter by dressing her in a hijab and adding "We Can Drive" to the caption. The Rosie the Riveter image is already commonly associated with feminism and feminist movements, and by commandeering the image as their own, the campaign and Middle Eastern feminists harness and reimagine the power of a symbol from Western feminisms for their movement and the Women2Drive campaign. Using the Rosie the Riveter image allows these non-Western feminists to engage with Western feminisms on their terms. They allow the power and credibility of Western feminisms to ally with them in a way that empowers rather than oppresses these already marginalized feminists. This engagement opened a door for globalized support of women from various contexts and showed a token of progress. Women across the world have come together in rallies and protests to lend their support to the Women2Drive Campaign. Other highly popularized images by the Women2Drive campaign are photos of women getting their driver's licenses and driving cars. Not only are these images attention-getting in a country where women have been all but officially banned from driving, but they also show women in the social action of these movements.

\section{Conclusion}

A limitation of this paper is that first-hand and scholarly work on these movements is limited and those most qualified to speak about Middle Eastern feminisms are either reluctant (for reasons of security) or their marginalized voices are not provided a platform. Future research should look at the organizational structure and the distribution of power within these movements, with an eye to democratic practices and distribution of power. Scholars have long attempted to explain and understand feminist social movements by examining the US or UK feminist movements, with a great deal of attention to second-wave feminism. In the past few decades, scholars and activists have examined women of color feminism (e.g. Moraga \& Anzaldua, 1981; Lugones, 2007) and black feminism (e.g., Collins, 1990; hooks, 1984; Richie, 2012). There has also been increased attention to social movements and social action related to global and international feminisms (e.g. Desai, 2015; Dickinson \& Schaeffer, 2001). In an increasingly globalized world, news and information about events and cultures outside one's own country is relatively easy to access, particularly via social media, viral videos, etc. Nonetheless, the dominance of the news and movements from Western cultures often overshadows the news and movements from non-Western countries. One consequence is that the dominant understanding of feminism in the West largely fails to consider non-Western feminisms.

In this paper, I have discussed Middle Eastern feminist movements, focusing on topics often addressed by social movement scholars. By examining social action, protest cycles, resource mobilization, movement and media framing, and the development of both secular and Islamic feminist movements, I illuminate their strengths and challenges. Both movements have made full use of the internet and social media as a resource and an avenue for mobilizing other resources. This has in turn attracted more social movement actors, widened the scope and reach of their social action, and made more resources available to them. Conversely, each movement demonstrates a diffusion of power, resulting in no firm recognizable leader. Islamic feminism is combating traditional and highly ingrained interpretations of Islam, forcing feminists in this movement to contest many aspects of their culture. In contrast, secular feminism is striving for change completely outside of the religious framework, which often frames this group as imposing 
Western ideals and may result in highly polarized opposition to their social action.

This discussion also demonstrates clearly that the dominance of Western feminisms as the ideal of feminist social movements must be questioned and resisted in order to make room for the pluralism of modern feminisms that include these non-Western feminist perspectives. In recent years, efforts have been made to make Western feminisms more inclusive and in particular to center the experiences of marginalized women. This suggests that Western feminisms have the capacity to recognize and support Middle Eastern feminisms. Moreover, international and global feminist movements are increasingly relevant, with feminisms in the MENA region holding important space in those movements. Although Middle Eastern feminist movements have not received sufficient attention from scholars or from Western feminist activists, there is no doubt that the Islamic feminist movement and the secular feminist movement are making strides for women in their cultures.

\section{References}

Abu-Lughod, L. (1998). Contentious theoretical issues: Third world feminisms and identity politics. Women's Studies Quarterly, 26(3/40), 25-29.

Abu-Odeh, L. (1993). Post-colonial feminism and the veil: Thinking the difference. Feminist Review, 26(43), 15271537.

Ahmadi, F. (2006). Islamic feminism in Iran: Feminism in a new Islamic context. Journal of Feminist Studies in Religion, 22(2), 33-53.

Ahmed, L. (1982). Feminism and feminist movements in the Middle East, a preliminary exploration: Turkey, Egypt, Algeria, People's Democratic Republic of Yemen. Women's Studies International Forum, 5(2), 153-168.

Al-Dosari, H. (2011, June 16). Saudi women drivers take the wheel on June 17. Al Jazeera. Retrieved from http://www.aljazeera.com/indepth/opinion/2011/06/201161694746333674.html.

Amini, A. (2008, January 16). Stop Stoning Forever Campaign | Violence is Not Our Culture. Retrieved from http://www. violenceisnotourculture.org/content/stop-stoning-forever-campaign.

Anzaldúa, G. (1987). Borderlands: La frontera (Vol. 3). San Francisco: Aunt Lute.
Badran, M. (2005) Between secular and Islamic feminism/s: Reflections on the Middle East and beyond. Journal of Middle East Women's Studies, 1(1), 6-28.

Basu, M. (2009, June 19). Women in Iran march against discrimination. CNN.com. Retrieved from http://www.cnn. com/2009/WORLD/meast/06/19/iran.protests.women/.

Bew, J. (2014, August 21). The tragic cycle: Western powers and the Middle East. New Statesman. Retrieved from http://www.newstatesman.com/world-affairs/2014/08/ tragic-cycle-western-powers-and-middle-east.

Boland, C. (2014, October 7). Islamic Feminism: Fighting discrimination, inspired by faith. Your Middle East. Retrieved from http://www.yourmiddleeast.com/columns/ article/islamic-feminism-fighting-discrimination-inspired-by-faith 11257 .

Bunch, C. (1990). Women's rights as human rights: Toward a re-vision of human rights. Human Rights Quarterly, 12(4), 486-498.

Cervantes-Altamirano, E. (2013). Islamic feminism and the challenges of gender, sexuality and LGBTQ rights in contemporary Islam. The International Journal of Religion and Spirituality in Society, 2, 76-85.

Choo, H. Y., \& Ferree, M. M. (2010). Practicing intersectionality in sociological research: A critical analysis of inclusions, interactions, and institutions in the study of inequalities. Sociological Theory, 28(2), 129-149.

Collins, P. H. (2002). Black feminist thought: Knowledge, consciousness, and the politics of empowerment. Routledge.

Crenshaw, K. (1991). Mapping the margins: Intersectionality, identity politics, and violence against women of color. Stanford Law Review, 43(6), 1241-1299.

Desai, M. (2015). Subaltern movements in India: Gendered geographies of struggle against neoliberal development (Vol. 100). Routledge.

Dickinson, T. D., \& Schaeffer, R. K. (2001). Fast Forward: Work, Gender, and Protest in a Changing World. Rowman \& Littlefield.

Earth Porm. (2015) Iranian women are posting pics with their hair flying free in protest of strict hijab laws. [Weblog post]. Retrieved from http://www.earthporm.com/stricthijab-laws/?utm_rcreplace_392 $=465$.

Edbadi, S. (2003) Shirin Ebadi - Nobel Women's Initiative. Retrieved from http://nobelwomensinitiative.org/ meet-the-laureates/shirin-ebadi/.

Ferrante, J. (2016). Seeing Sociology: An Introduction (3rd ed.). (pp. 55) Boston, MA: Cengage Learning.

Garry, A. (2011). Intersectionality, metaphors, and the multiplicity of gender. Hypatia, 26(4), 826-850.

hooks, b. (2000). Feminist theory: From margin to center. Pluto Press.

International Campaign for Human Rights in Iran. (2011, May 24). One Million Signatures Campaign. Retrieved from http://www.iranhumanrights.org/tag/one-million-signatures-campaign/. 
Jamjoon, M. (2011, June 20) Saudi women defy driving ban. CNN.com. Retrieved from http://www.cnn.com/2011/ WORLD/meast/06/17/saudi.women.drivers/.

Lugones, M. (2007). Heterosexualism and the colonial/modern gender system. Hypatia, 22(1), 186-219.

Malik, N. (2011, June 3). Saudi Arabia's women2drive campaign is up against society. theguardian. Retrieved from http://www.theguardian.com/commentisfree/2011/ jun/03/saudi-arabia-women2drive-women-driving.

Moller Okin, S. (1998) Feminism, women's human rights, and cultural differences. Hypatia, 13(2), 32-52.

Moraga, C., \& Anzaldúa, G. (Eds.). (2015). This bridge called my back: Writings by radical women of color. SUNY Press.

Owen, A. \& Ward, F. (Producers), \& Gavron, S. (Director). (2015, October 12). Suffragette [Motion picture]. United Kingdom: Pathé.

Quesada, U., Gomez, L., \& Vidal-Ortiz, S. (Eds.). (2015). Queer brown voices: Personal narratives of Latina/o LGBT activism. University of Texas Press.

Raghavan, S. (2009, June 28) Role of women in Iran protest kindles hope. The Washington Post. Retrieved from http://www.washingtonpost.com/wp-dyn/content/article/2009/06/27/AR2009062702416.html.

Richie, B. (2012). Arrested justice: Black women, violence, and America's prison nation. NYU Press.

Seedat, F. (2013). Islam, feminism, and Islamic feminism. Journal of Feminist Studies in Religion, 29(2), 25-45.

Stop Stoning Forever Campaign. (2006, December 6). UPDATE: Iran: 'stop stoning forever' campaign. Retrieved from http://www.wluml.org/node/119.

Stop FGM Middle East. (2016). The Campaign. Retrieved from http://www.stopfgmmideast.org/.

Tavaana. One million signatures: The battle for gender equality in Iran case study. Retrieved from https://tavaana.org/ en/content/one-million-signatures-battle-gender-equality-iran.

(2015). Timeline of contemporary Muslim women's activism. [Weblog post]. Retrieved from http://www.wisemuslimwomen.org/activism/timeline results/C84/1993-2003.

Wagner, R. L. (2012, February 2). Islamic Feminism in the Middle East. International Policy Digest. Retrieved from http://www.internationalpolicydigest.org/2012/02/02/ islamic-feminism-AAWWWWWWWWWWin-the-middle-east/.

Wilkinson, P. (2012, August 24). 'Honor' crime: Why just kissing a boy can trigger murder. Cnn.com. Retrieved from http://www.cnn.com/2012/08/24/world/europe/ uk-honor-murder-sanghera/.

WISE Muslim Women. Directory of women's organizations/ campaigns. [Weblog post]. Retrieved from http://www. wisemuslimwomen.org/activism/.
Women's Learning Partnership. Iran's one million signatures campaign. Retrieved from http://www.learningpartnership.org/iran-oms.

\section{Author Note}

The author would like to thank the following individuals for their support of this project: Melissa Burke, Dr. Laura Logan, Kamerin McKinley, and Sydney Sheldrick. 